\title{
Spinal extradural cysticercosis: a case report
}

\author{
A Mohanty, S Das, VR Sastry Kolluri and BS Das \\ Departments of Neurosurgery \& Neuropathology, National Institute of Mental Health \& Neuro Sciences, Bangalore, \\ India
}

\begin{abstract}
An extremely rare case of extradural spinal cysticercosis in an adult male is presented. The patient had evidence of extradural granulation tissue with associated destruction of $\mathrm{C}_{4}$ and $\mathrm{C}_{5}$ pedicles and laminae, causing tetraparesis. Histopathological examination revealed evidence of a degenerated cysticercal cyst with host tissue reaction. The patient made a gradual and marked improvement after decompression. Though rare, cysticercosis as a possible etiology of extradural spinal compression may be considered in endemic area.
\end{abstract}

Keywords: cysticercosis; extradural; spinal compression; spinal cysticercosis

\section{Introduction}

Cysticercosis is the commonest parasitic disease affecting the central nervous system. However, spinal involvement occurs only in $0.7-5.85 \%$ of the patients with neurocysticercosis. ${ }^{1,2}$ Spinal cysticercosis can be intramedullary, subarachnoid (leptomeningeal) or extradural in location. Involvement of the vertebral column by the parasite is extemely rare. ${ }^{3,4}$ We report a case of cervical extradural and vertebral cysticercosis causing tetraparesis, and review the available literature.

\section{Case report}

A 55 year old labourer presented with paraesthesiae and progressive weakness of all four limbs of 5 months duration. There was no history of bladder or bowel dysfunction. He was bedridden for 2 months prior to admission.

General physical examination was normal. Neurological examination revealed normal higher mental functions, optic fundi and cranial nerves. He had spastic tetraparesis with muscle wasting of the arms and clawing of both hands. The motor power was $3 / 5$ in both arms and $2 / 5$ in the legs with flexor spasms (ASIA Impairment Scale: C, Incomplete). ${ }^{5}$ There was graded sensory loss to pain and touch sensation below C5 level bilaterally. The upper limb reflexes were sluggish and those in the lower limbs brisk.

Hematological evaluation revealed a total leukocyte count of $9600 / \mathrm{cmm}$, differential count of neutrophils $78 \%$, eosinophils $2 \%$ and lymphocytes of $20 \%$. The erythrocyte sedimentation rate by Westergren's method was $51 \mathrm{mms} / 1 \mathrm{st}$ hour. The biochemical parameters were normal. The chest radiograph was normal. Plain

Correspondence: Dr. A Mohanty, M. Ch., radiographs of the cervical spine demonstrated spondylotic changes. Lumbar Iohexol myelography revealed a total block of the contrast flow opposite C6 body. An intrathecal contrast enhanced CT scan of the cervical spine showed an extradural lesion at C4, 5, 6 levels compressing the spinal dura from the left dorsal aspect. There was evidence of destruction of $\mathrm{C} 4$ and C5 pedicles and laminae on the left side (Figure 1a and b). A diagnosis of cervical tuberculosis with extradural granulation tissue was made preoperatively.

Laminectomy from $\mathrm{C} 2-\mathrm{C} 7$ was carried out, and the C5 laminae were found to be destroyed, as was the left C4 laminae. Greyish yellow colored vascular granulation tissue compressing the dural tube was seen extradurally. It was extending extraspinally and was involving the paraspinal muscles. Adequate decompression of the spinal cord was performed.

Histopathological examination of the extradural tissue comprising fragments of bony trabeculae and soft tissue was performed. The latter showed the degenerated wall of a cysticercal cyst with infiltration by acute and chronic inflammatory cells adjoining the cyst wall (Figure 2a). Fragments of degenerated cyst wall were also seen between the extradural connective tissue and the adjoining skeletal muscle. A decalcified section of the operated specimen revealed bony trabeculae and marrow tissue with an inflammatory reaction (Figure 2b). Fragments of bony trabeculae were seen surrounded by lymphocytes, histiocytes and multinucleated giant cells suggestive of destruction of bone with reactive changes. Lumbar CSF analysis done in the postoperative period revealed four cells (lymphocytes), the CSF glucose was $83 \mathrm{mg} \%$ and the proteins were $495 \mathrm{mg} \%$. The CSF was positive for anticysticercal antibodies by Enzyme linked immunosorbent assay (ELISA) test. A cranial CT scan and soft tissue radiographs carried out later for possible cysticercus cysts elsewhere were negative. 
a

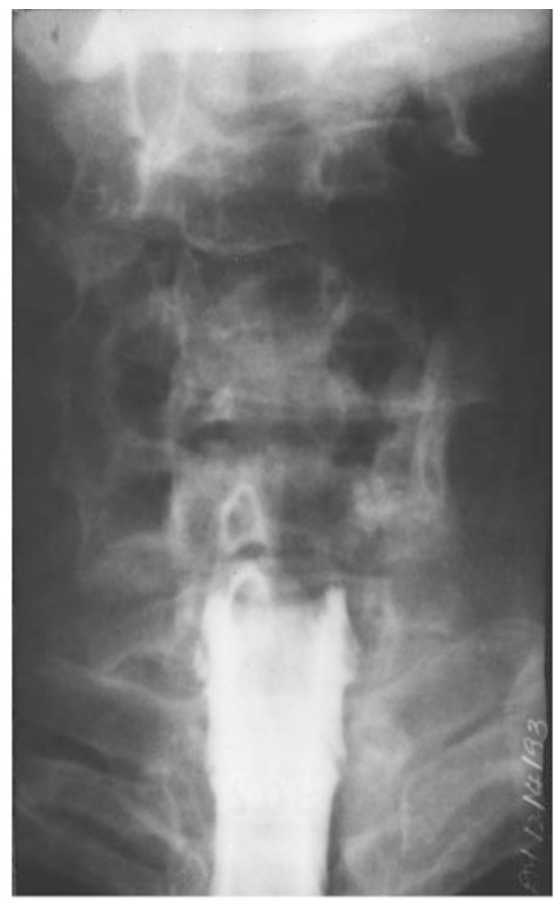

b

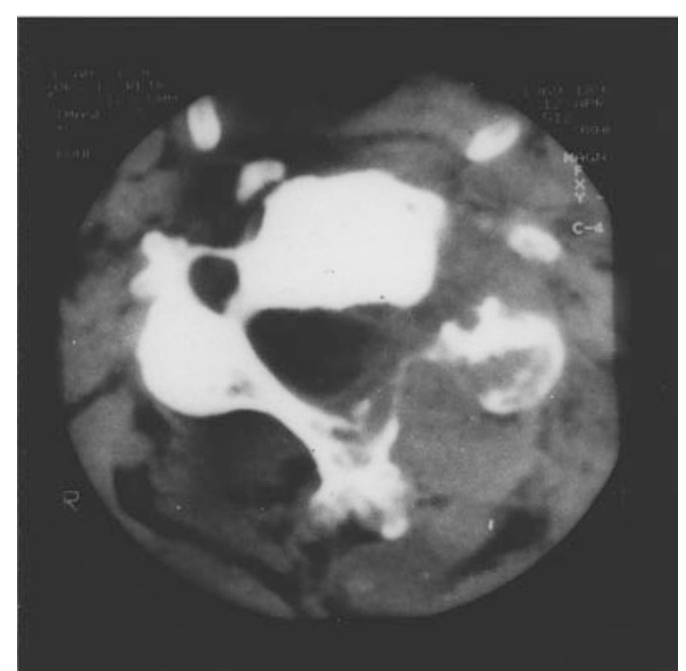

Figure 1 (a) Iohexol myelogram of the cervical region (AP view) demonstrating a complete block at $\mathrm{C} 6-7$ level. (b) Intrathecal contrast $\mathrm{CT}$ scan at $\mathrm{C} 4$ level demonstrating erosion and destruction of the lamina, pedicle and the transverse process on the left side

In the post-operative period, the patient was started on oral albendazole $15 \mathrm{mg} / \mathrm{kg}$ body weight for 4 weeks, supplemented with corticosteroids for the initial 2 weeks. He made a gradual neurological recovery and after a period of 2 years is able to walk with support and pursue his daily activities (Level 6, Functional Independence Measure, IMSOP/ASIA Scale). ${ }^{5}$

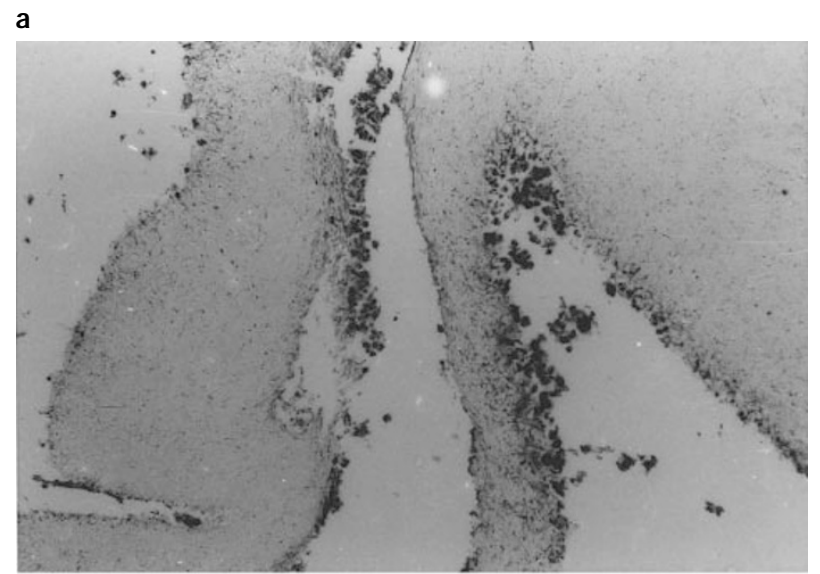

b

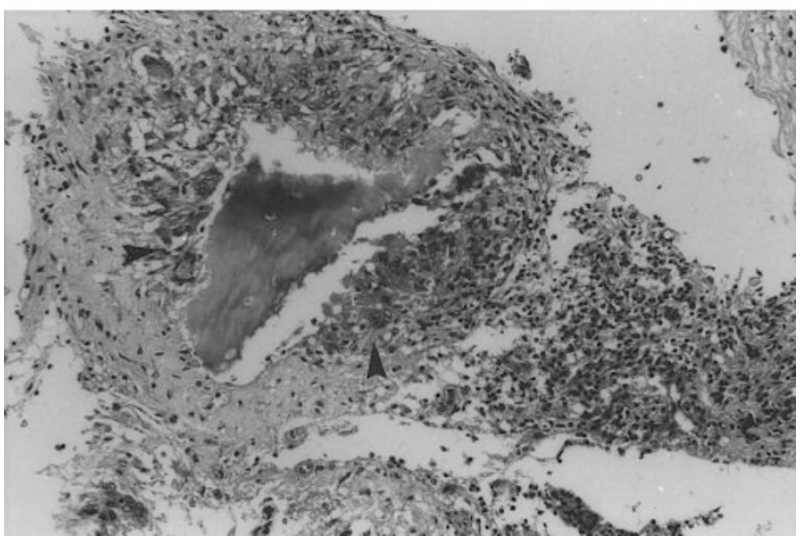

Figure 2 (a) Photomicrograph showing fragments of degenerated wall of the cysticercal cyst (Haematoxylin and Eosin $\times 200$ ). (b) Decalcified section of the pathological specimen showing bony trabeculae surrounded by chronic inflammatory tissue and giant cell reaction (arrows) (Haematoxylin and Eosin $\times 200$ )

\section{Discussion}

Spinal cysticercosis is an uncommon manifestation of neurocysticercosis, comprising $0.7-5.85 \%$ of all cases of neurocysticercosis. ${ }^{1,2}$ It can be extradural, subarachnoid (leptomeningeal) or intramedullary in location. The subarachnoid form is the commonest followed by the intramedullary and the extradural forms. Downward migration of the larvae from the cerebral to the spinal subarachnoid spaces results in the leptomeningeal form of spinal cysticercosis. ${ }^{1}$ Hematogenous dissemination and spread through the ventriculoependymal pathways have been postulated as the modes of involvement for the intramedullary forms. ${ }^{2}$

The extradural type of spinal cysticercosis is the most uncommon and the authors could only collect examples from the English literature., ${ }^{3,6}$ Involvement of the vertebral column was present in two patients 3,4 and the other had a cyst attached to the lumbar nerve root $\operatorname{sheath}^{6}$ (Table 1). Extradural granulation tissue 
Table 1 Reported cases of spinal extradural cysticercosis

\begin{tabular}{|c|c|c|c|c|c|c|}
\hline $\begin{array}{l}\text { Sl. } \\
\text { No. }\end{array}$ & Author & $\begin{array}{l}\text { Agel } \\
\text { Sex }\end{array}$ & Clinical presentation & $\begin{array}{l}\text { Radiological } \\
\text { investigation }\end{array}$ & Operative findings & Outcome \\
\hline 1 & $\begin{array}{l}\text { Shadangi, } \\
\text { et al } \\
\text { (1977) }\end{array}$ & $\begin{array}{l}25 / \\
M\end{array}$ & $\begin{array}{l}\text { Low back ache with } \\
\text { radiculopathy }\end{array}$ & $\begin{array}{l}\text { Myelogram: Extradural } \\
\text { filling defect in } \\
\text { lumbosacral region }\end{array}$ & $\begin{array}{l}\text { Single cyst, attached to } \\
\text { L5 nerve root excised }\end{array}$ & $\begin{array}{l}\text { Improved, had } \\
\text { no deficits }\end{array}$ \\
\hline 2 & $\begin{array}{l}\text { Kurrein, } \\
\text { et al } \\
(1977)\end{array}$ & $\begin{array}{l}\text { Adult/ } \\
\text { M }\end{array}$ & $\begin{array}{l}\text { Had partial Brown } \\
\text { Sequard Syndrome } 19 \\
\text { years prior, operated \& } \\
\text { intraspinal cysticercal } \\
\text { cyst removed; presented } \\
\text { with persistant low back } \\
\text { ache }\end{array}$ & $\begin{array}{l}\text { Dislocation of L1, L2 } \\
\text { vertebrae with } \\
\text { expanding lesion at L2 } \\
\text { vertebra }\end{array}$ & $\begin{array}{l}\text { Needle biopsy of body } \\
\text { of vertebra revealed } \\
\text { cysticercal cyst. } \\
\text { Underwent spinal } \\
\text { stabilisation procedures }\end{array}$ & $\begin{array}{l}\text { Expired, autopsy } \\
\text { done revealed } \\
\text { cysts and } \\
\text { chronic } \\
\text { inflammatory } \\
\text { cells in the body } \\
\text { of vertebra }\end{array}$ \\
\hline 3 & $\begin{array}{l}\text { Vlok, } \\
\text { et al } \\
(1988)\end{array}$ & $\begin{array}{l}45 / \\
\mathrm{M}\end{array}$ & $\begin{array}{l}\text { Progressive spastic } \\
\text { paraparesis }\end{array}$ & $\begin{array}{l}\text { Destruction and } \\
\text { compression of } \mathrm{T} 11, \\
\text { total obstruction of } \\
\text { contrast column at } \mathrm{T} 11 \\
\text { in myelogram }\end{array}$ & $\begin{array}{l}\text { Paravertebral soft tissue } \\
\text { mass with cysts, T11 } \\
\text { body contained cysts }\end{array}$ & Improved \\
\hline 4 & $\begin{array}{l}\text { Present } \\
\text { case }\end{array}$ & $\begin{array}{l}55 / \\
\mathrm{M}\end{array}$ & $\begin{array}{l}\text { Progressive spastic } \\
\text { tetraparesis }\end{array}$ & $\begin{array}{l}\text { Extradural type of } \\
\text { block at C6 level. } \\
\text { Destruction of C4, } \\
\text { C5 pedicles and } \\
\text { laminae in CT scan }\end{array}$ & $\begin{array}{l}\text { Extradural granulation } \\
\text { at } \mathrm{C} 4,5,6 \text { with } \\
\text { destruction of laminae }\end{array}$ & Improved \\
\hline
\end{tabular}

causing compression was not present in any of the three cases.

Our patient had evidence of destruction of the posterior elements of the cervical spine at two levels with associated extradural granulation tissue causing compression of the theca and spinal cord. The granulation tissue showed evidence of degenerated parasitic cysts, indicative of its inflammatory nature.

In the three previously reported cases, as well as in the present case, a preoperative diagnosis of cysticercosis was considered in only one patient, who was previously diagnosed to have cervical cysticercosis at a prior surgical operation. ${ }^{3}$ In the present case, also, a preoperative diagnosis of cysticercus etiology was not considered, and it could only be made after the histopathological examination, and was supported by the ELISA study reports for anticysticercal antibodies.

Surgical excision of the granulation tissue or/and the cystic masses along with excision of the involved vertebral segments is the preferred treatment for extradural cysticercosis. ${ }^{4}$ Our patient improved after the decompression operation. Spinal stabilization procedures can also be performed if indicated. ${ }^{4}$ The role of anticysticercal treatment without surgery in the extradural type of cysticercosis is not clear, although it has been suggested for spinal cysticercosis. ${ }^{7}$ A course of anticysticercal treatment in the post-operative period is advised as cysticercosis is a systemic disease with focal manifestations.

\section{References}

1 Quieroz LDS, Filho AP, Callegaro D, Faria LLD. Intramedullary cysticercosis: Case report, literature review and comments on pathogenesis. J Neurol Sci 1975; 26: $61-70$.

2 Sotello J, Guerrero V, Rubio F. Neurocysticercosis: A new classification based on active and inactive forms. A study of 753 cases. Arch Intern Med 1985; 145: $442-445$.

3 Kurrien F, Vickers AA. Cysticercosis of the spine. Ann Trop Med Parasitol 1977; 71: 213-217.

4 Vlok GJ, Wells MC. Vertebral cysticercosis. A case report. $S$ Afr Med Journal 1988; 73: 730-731.

5 Ditunno JF, Young W, Donovan WH, Creasey G. The international standards booklet for neurological and functional classification of spinal cord injury. Paraplegia 1994; 32: 70-80.

6 Shadangi TN, Abraham J. An extradural cysticercus attached to lumbar nerve root. Neurol Ind 1977; 25: $43-45$.

7 Del Brutto OH. Diagnosis and management of cysticercosis. $J$ Trop Geograph Neurol 1992; 2: 1-9. 